\title{
AN EXAMPLE OF CHANGES IN URBAN PERIPHERY: FAMILY AGRICULTURE TESTED BY URBAN DYNAMICS IN THE MUNICIPALITY OF ABOMEY-CALAVI (SOUTH BENIN)
}

\author{
Bola A. MALOMON, Sylvain A. VISSOH and Komi D. FOLY ${ }^{1}$ \\ ${ }^{1} \mathrm{PhD}$ student, "Multidisciplinary Doctoral School - Spaces, Cultures and Development", University of Abomey- \\ Calavi (Benin), Laboratory of Urban and Regional Dynamics Studies (LEDUR), \\ ${ }^{2}$ Laboratory for Urban and Regional Dynamics Studies (LEDUR), Department of Geography and Regional Planning \\ (DGAT) of the University of Abomey-Calavi (Benin) \\ https://doi.org/10.35410/IJAEB.2021.5666
}

\begin{abstract}
Urban outskirts often experience changes that affect human activities. The aim of this research is to analyze the effects of peri-urban dynamics on family farming in the Municipality of AbomeyCalavi.

The adopted methodology is based on documentary research, field surveys, processing of collected data and analysis of results. Fieldwork carried out using a questionnaire, an interview guide and an observation grid led us to travel through 18 villages and city districts spread across the seven (7) outlying districts of the city of Abomey-Calavi. During these surveys, 150 people were interviewed. The State-Pressure-Impact-Response (EPIR) analysis model was used to analyze changes in agricultural land in the outskirts of the city of Abomey-Calavi.

It emerges from the results that the peripheral area of the city of Abomey-Calavi has been experiencing significant dynamics both demographically and spatially in recent years. Between 2000 and 2020, the area of mosaics of crops and fallows experienced a reduction of 9,691.5 ha from $27,740.7$ ha to $25,329.318$ ha (or 484.57 ha per year) while that of agglomerations fell. Increased by 9889.49 ha from 1436.91 ha to 4294.38 ha with an annual growth rate of $34.41 \%$. The formerly agricultural lands are therefore now the object of greed and commodification on the part of city dwellers.
\end{abstract}

It is urgent that the local authorities take measures for optimal management of the peri-urban space in order to preserve family farming in the Municipality of Abom.

Keywords: Abomey-Calavi, peri-urban dynamics, family farming, land issues.ey-Calavi.

\section{INTRODUCTION}

In Africa, the expansion of cities creates hybrid spaces, mixing urban and rural characteristics. Agricultural, industrial and residential spaces make up a complex, often confused mosaic, where land use is multiple and difficult to read (S. Dauvergne, 2011, p. 22). The management of these changing areas, welcoming an increasingly large population, is crucial because it poses many challenges, particularly at the local level. 
Since the 1990s, Benin has experienced remarkable urban growth with an urbanization rate that rose from $35.7 \%$ in 1992 to $38.9 \%$ in 2002 before reaching 44.6\% in 2013 (CM Atodjinou and al., 2015, p.2). This situation has favored the rapid development of cities in terms of demography and space.

In the Municipality of Abomey-Calavi, the settlement of populations in the peripheral area leads to a strong demand for building plots, hence land speculation. For A. B. Malomon (2018, p. 57), local authorities find it difficult to master land issues in this area because the interests are far too important for the land use rules enacted to be applied normally.

The present work proposes to determine the explanatory factors of the dynamics of the periurban space in the Municipality of Abomey-Calavi, on the one hand, and on the other, to analyze the consequences of this dynamic on family farming

\section{MATERIALS AND METHODS}

\subsection{Geographical scope of the research}

This research focuses on the Municipality of Abomey Calavi. It is located in the Atlantic Department (South Benin), more precisely between the parallels $6^{\circ} 20$ 'and $6^{\circ} 41$ "north latitude and the meridians $2^{\circ} 12^{\prime}$ and $2^{\circ} 26^{\prime \prime}$ east longitude. It is bounded to the north by the Municipality of Zè, to the south by the Atlantic Ocean, to the east by the municipalities of SôAva and Cotonou and to the west by the municipalities of Tori-Bossito and Ouidah. With its 539 $\mathrm{km} 2$, the Municipality of Abomey-Calavi is the largest in the Atlantic department (20\% of the area of the department). Administratively, the town has nine (09) districts namely AbomeyCalavi, Glo-Djibgé, Godomey, Hêvié, Kparoun, Ouêdo, Togba and Zinvié.

Figure 1 shows the geographical location of the Municipality of Abomey - Calavi.

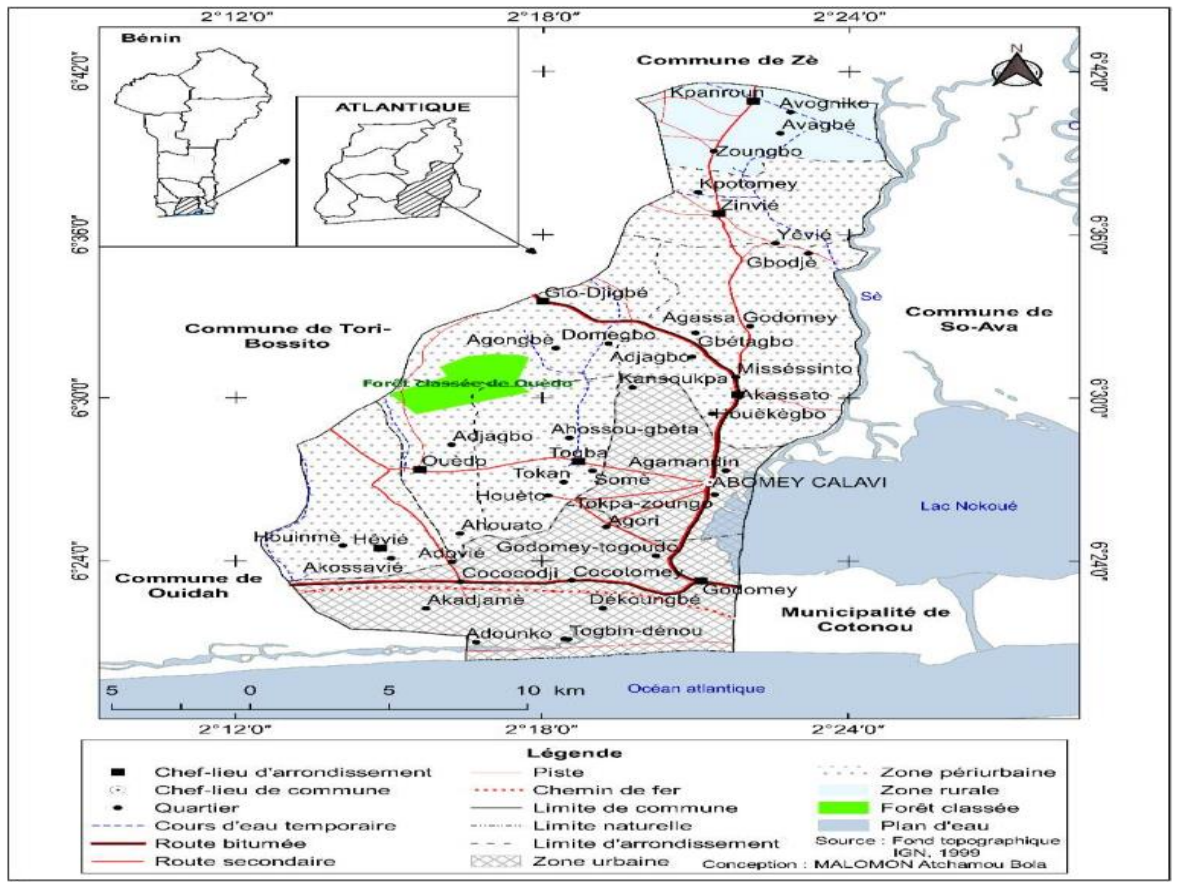

Figure 1: Geographical location of the Municipality of Abomey-Calavi 


\subsection{Data used}

The data used in the context of this work are qualitative and quantitative. It's about data: -demographic from the 1979, 1992, 2002 and 2013 censuses, taken from the directories of the National Institute for Statistics and Economic Analysis (INSAE).

- relating to land use between 1990 and 2020

- relating to the modes of access and use and to land documents (the number of agreements established, the price and the reasons for the sale of agricultural plots, especially in peripheral areas)

\subsection{Techniques, tools and materials for data collection}

The selection of the districts and villages, in which the surveys are carried out, is made on the basis of the following criteria: the demographic weight of the district or the village, the presence of a large number of agricultural households, the existence of numerous land transactions over the last thirty (30) years and the observation of changes linked to urban sprawl. The unit of survey is the farm household. The criteria used in the context of this research are, among others: to be at least twenty-five (25) years old, to have lived in the locality at least for the last ten years before the survey, to be a domain owner. These criteria were chosen because of the complexity of the land tenure phenomenon which requires a certain residential age for its understanding.

The field surveys took place in the outlying districts of the city of Abomey-Calavi, namely Akassato, Togba, Glo-Djigbé, Hêvié, Zinvié and Ouèdo and Kpanroun. Fourteen (14) villages were visited at the rate of two villages per district. For the quantitative survey, the sample size at the level of each district was determined according to the probabilistic theory of D. Schwartz (1995):

$\mathrm{X}=\mathrm{Z} \alpha 2 \mathrm{x} \mathrm{pq} / \mathrm{i} 2$ (1) with $\mathrm{x}=$ sample size, $\mathrm{Z} \alpha=1.96$ Reduced deviation corresponding to a risk $\alpha$ of $5 \% ; \mathrm{p}=\mathrm{n} / \mathrm{N}$ with $\mathrm{p}=$ proportion of households in each district or village (n) compared to the total number of households in the district $(\mathrm{N})$ in which the latter is located, $\mathrm{q}=1-\mathrm{p}$ and $\mathrm{i}$, the precision desired equal to $5 \%$.

The data collection in the field was carried out in two stages: a first stage made of direct observations in the field with the support of an observation grid. Occasionally, photos have been taken to illustrate this document. The second step consisted of interviewing 80 heads of agricultural households and other actors involved in the land issue, including district heads (07), village heads (14), and heads of farmer organizations (07). A total of 150 people were questioned.

The equipment used to collect data in the field consists of a camera, a sound recorder and a GPS (Global Positioning System)

\subsection{Data processing and results analysis}


The survey sheets were analyzed and the quantitative data were processed and presented in the form of tables and figures. The statistical variables used are those of descriptive statistics (arithmetic mean, percentage, frequency, etc.). Excel 2013 and SPSS software made it possible to build up a database and perform statistical processing. The maps were made using Arc View 3.2 software.

The EPIR (State-Pressure-Impact-Response) model was used for the analysis of results.

\section{RESULTS}

3.1 Explanatory factors for the dynamics of peri-urban space in the Municipality of Abomey-Calavi

\subsection{1- Spatial extensions linked to high residential mobility}

Like the spaces peripheral to the cities of Benin such as Porto-Novo, Cotonou and Parakou, that of the city of Abomey-Calavi welcomes many populations. This space, once dedicated to agriculture, now attracts populations of various origins (Figure 2).

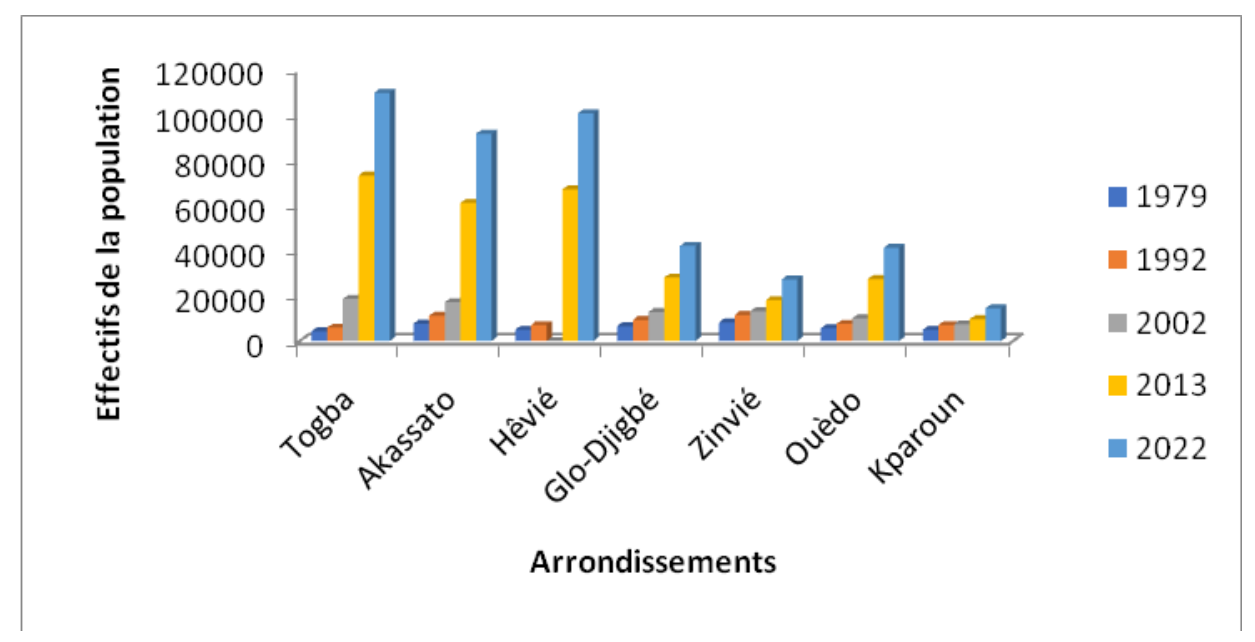

Figure 2: Evolution of population numbers in the peri-urban area in Abomey-Calavi

Source: INSAE, 2013

Figure 2 shows a constant change in the size of the population in the peri-urban area in AbomeyCalavi. These populations who settle in this space are actually city dwellers in search of building land. The land dynamics, consequence of this settling of populations, leads to a scarcity of agricultural spaces.

An analysis of the data from the last census (RGPH 4), shows that residential migration in particular increases the demographic weight of these peripheries, especially since the proportion of city dwellers who live there has experienced a significant increase in the total population (Figures 3, 4 and 5). 


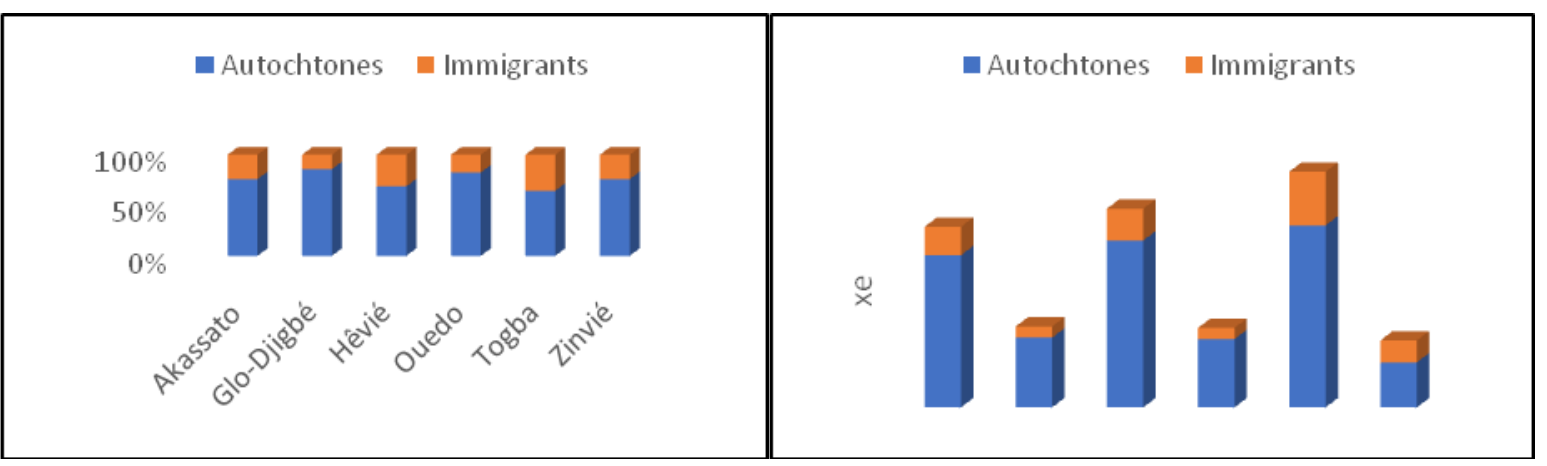

Figure 2: Rapport entre l'effectif des immigrants et l'effectif de la population en 2002

Source : INSAE 2002 (RGPH 3)
Figure 1 : Rapport entre l'effectif des immigrants et l'effectif de la population en 2013

Source : INSAE 2013 (RGPH 4)

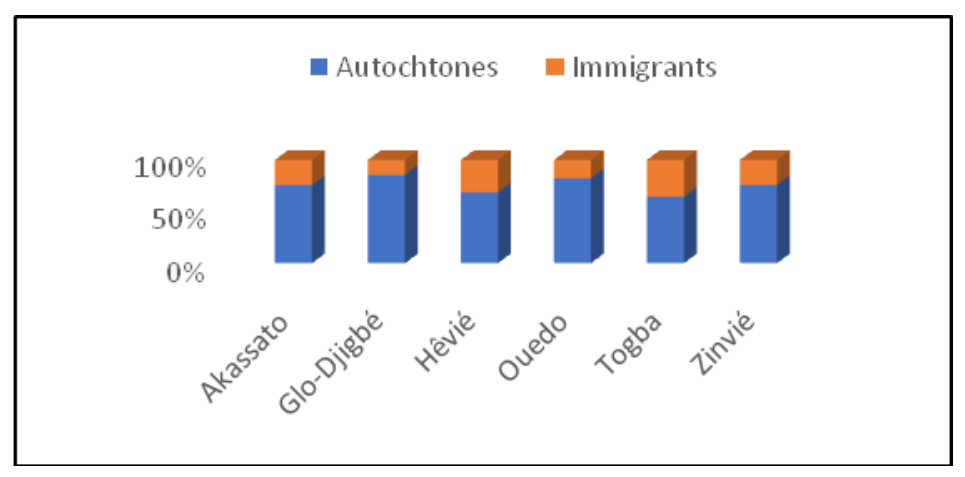

Figure 5: Ratio of the size of immigrants to the size of the population in 2020

Source: INSAE 2002 (RGPH 3) and projection results

Analysis of Figures 3, 4 and 5 shows that the outskirts of the city of Abomey-Calavi are welcoming more and more immigrants, mainly from the urban districts. In 2002, the first destinations for immigrants were the districts of Togba, Hêvié, Akasato and Zinvié. The same observation is made in 2013 and 2020 with an increase in the number of immigrants. In addition to these districts, Ouèdo and Glo-Djigbé, unlike Kpanroun, which is weakly impacted by the phenomenon of peri-urbanization.

Table I below shows the origin of the populations who settled in the peri-urban space of Abomey-Calavi. 
Table I: Origin of the populations settled in the peri-urban area of Abomey-Calavi.

\begin{tabular}{|lc|}
\hline \multicolumn{1}{|c|}{ Residential locations } & Percent of populations \\
\hline Cotonou & $18 \%$ \\
Abomey-Calavi center & $30,5 \%$ \\
Godomey center & $34,5 \%$ \\
Other localities & $17 \%$ \\
\hline Total & $\mathbf{1 0 0 \%}$ \\
\hline
\end{tabular}

Source: Field surveys, March 2020

The analysis of Table I shows that $83 \%$ of the populations settled in the peri-urban area of Abomey-Calavi come from urban centers (Abomey-Calavi center, Godomey center and Cotonou).

\subsection{2- Natural factors explaining the settlement of populations in peri-urban space}

Due to the geographical location of the Municipality of Abomey-Calavi, the urban expansion is towards the outlying areas where agriculture is largely practiced. Indeed, blocked to the south by the Atlantic Ocean and to the east by the Municipality of So-Ava and the coast, the Municipality of Abomey-Calavi can only extend north and west. This constraint makes localities such as Togba, Hevié and Akassato, but also Glodjigbé and Ouèdo, areas more favorable to the urbanization front.

2.1.3- The price of land, a factor that favors the settlement of populations in peri-urban space.

The high price of land in urban centers forces people to prefer peri-urban areas to these centers. Figure 6 below shows the evolution of plot prices in the agglomerated centers of Abomey-Calavi and Godomey between 1995 and 2019.

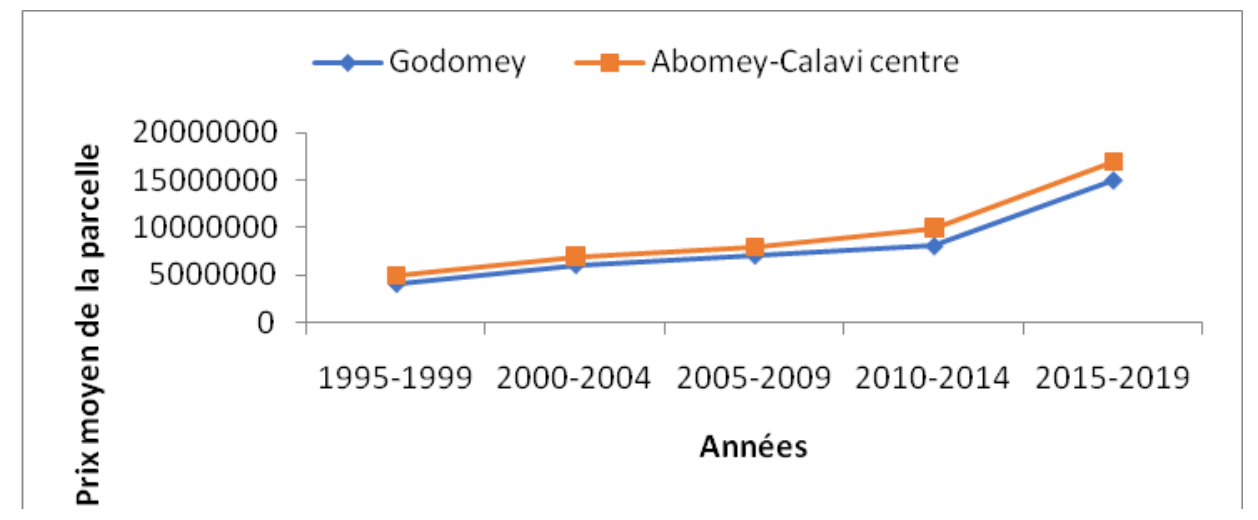


Figure 6: Evolution of the average price of a plot $(500 \mathrm{~m} 2)$ in the agglomerated centers of Abomey-Calavi

Source: Field surveys, August 2020

Figure 6 shows a constant evolution of the price of plots in the two urban districts; these prices go from 5,000,000 FCFA in the period 1995-1999 to 17,000,000 FCFA in the period 2015-2019 in Abomey-Calavi center and from 4,000,000 FCFA in 1995-1999 to 15,000,000 in 2015-2019 at Godomey Center. Under these conditions, the only possibility that exists for city dwellers wishing to access land ownership in the Municipality of Abomey-Calavi is to fall back on peripheral localities such as Togba, Akassato, Hèvié, Ouèdo and Glo-Djigbé.

3.1.4 Role of public authorities in the transformation of the peri-urban space in AbomeyCalavi

The state has undertaken the construction of several infrastructures in the outskirts of the city of Abomey-Calavi. Table II below shows the situation of these construction projects.

Table II: Situation of infrastructure construction projects in the peripheral area of the city of Abomey-Calavi.

\begin{tabular}{|l|c|c|}
\hline \multicolumn{1}{|c|}{ Names } & Zones & Area (ha) \\
\hline $\begin{array}{l}\text { Glo-Djigbé International Airport } \\
\text { construction project }\end{array}$ & Glo-Ddjigbé & 3028 ha 44a 19 ca \\
\hline Ajagbo Wholesale Market & ZOPAH & 168 ha 18 a 16 ca \\
\hline Social housing in Ouèdo (2008) & Ouèdo & 71 ha \\
\hline Social housing in Ouèdo (2020) & Ouèdo & 175 ha \\
\hline $\begin{array}{l}\text { CEB kw (330 kw Ko } \\
\text { interconnection line) }\end{array}$ & Kpoe- Kpanroun & \\
\hline
\end{tabular}

Source: Field surveys, November 2020

According to Table II, 3,452 ha 62a and $35 \mathrm{ca}$ of land are mobilized for the construction of infrastructure to the detriment of agriculture. Photo 1 shows a partial view of social housing under construction in the Arrondissement of Ouèdo

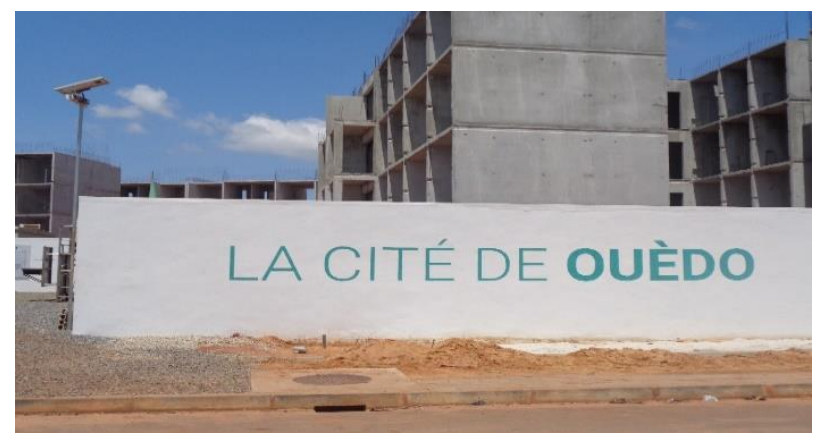


Photo 1: Partial view of social housing in Ouèdo (2020 project)

Shooting: A. B. Malomon, June 2021

Photo 1 shows a partial view of social housing under construction in the Arrondissement of Ouèdo. These constructions are certainly useful for housing populations, but they contribute to the reduction of agricultural land and therefore have a negative impact on the practice of family farming.

\subsection{Changes in land use}

Changes of use have been recorded in the land use of peri-urban space. Figures 7, 8 and 9 below show the evolution of the different land use units in the peripheral area of the city of AbomeyCalavi between 2000 and 2020.

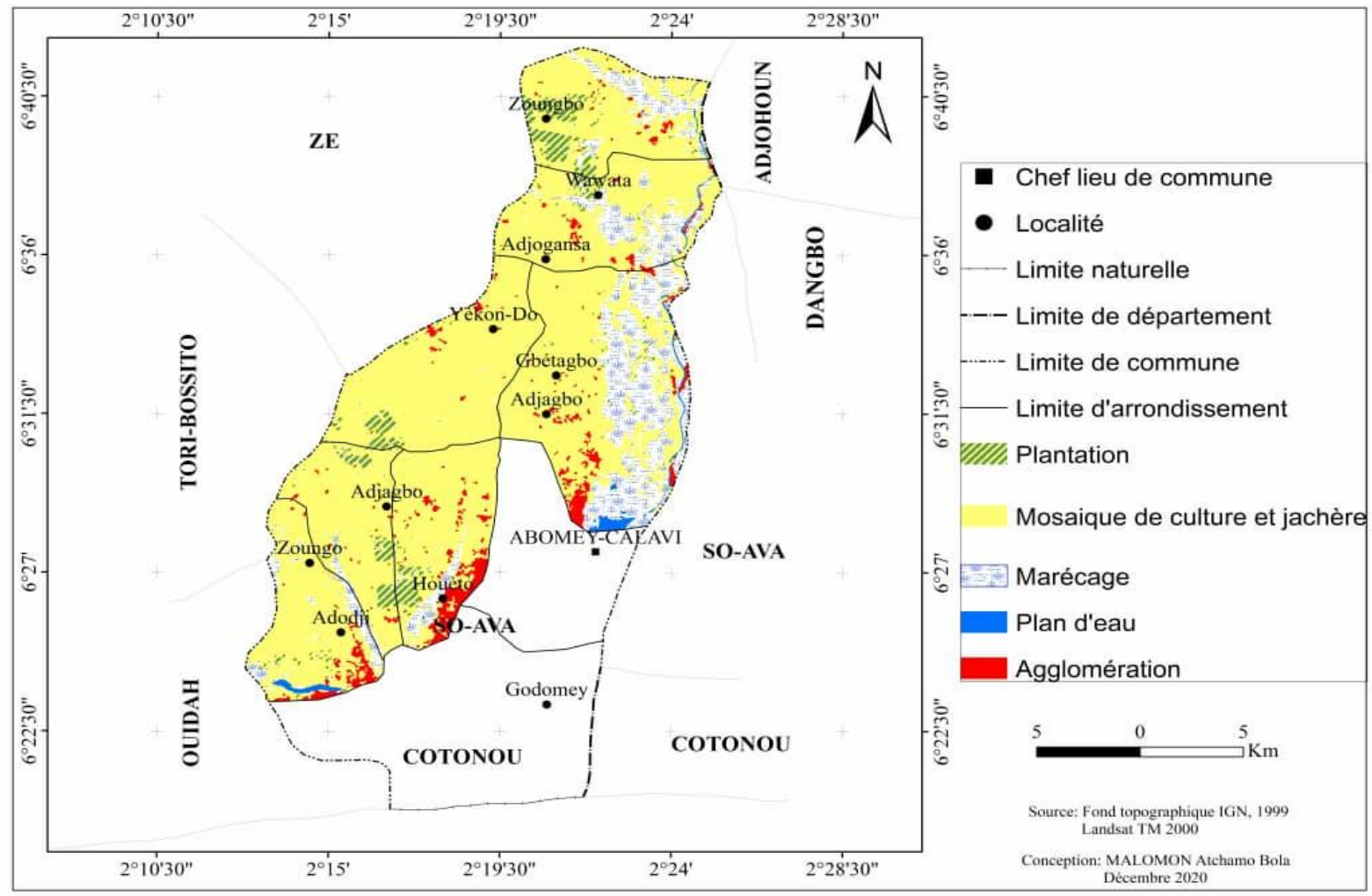

Figure 7: State of peri-urban land use in 2000 


\section{International Journal of Agriculture, Environment and Bioresearch}

Vol. 06, No. 05; 2021

ISSN: 2456-8643

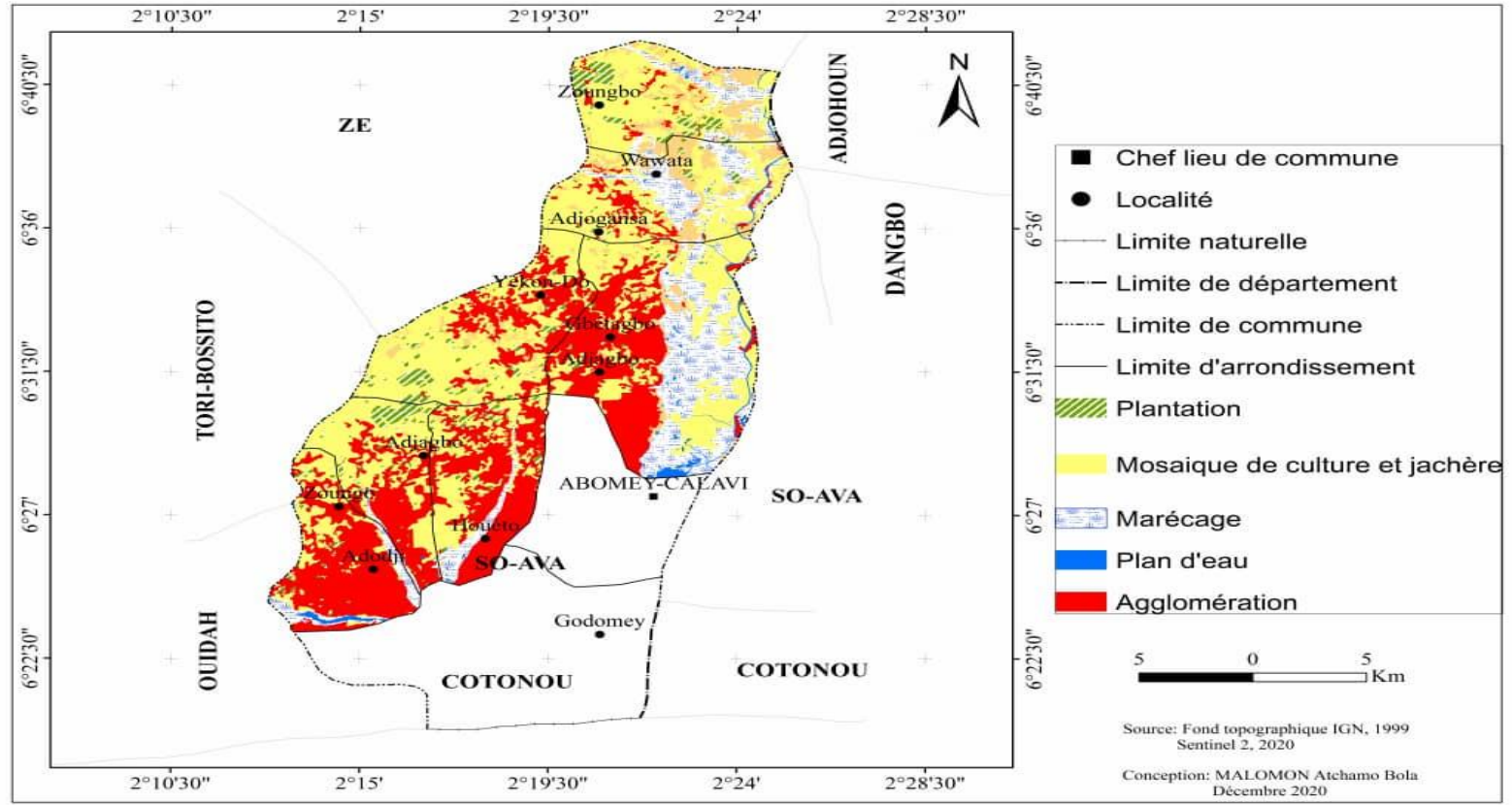

Figure 9: State of peri-urban land use in 2020

Figures 7, 8 and 9 show an extension of the inhabited space to the detriment of cultivable areas, particularly in the Arrondissements of Akassato, Togba, Hêvié, Ouèdo and Glo-Djigbé. Figure 10 shows the different land use units in 2000, 2010 and 2020.

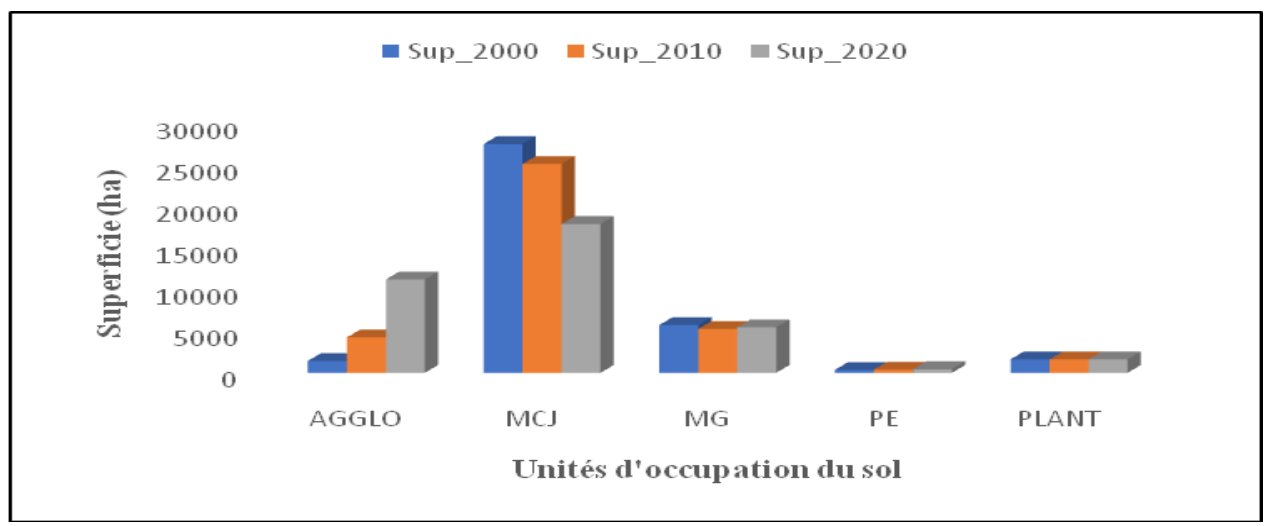

Figure 10: State of land use in the peripheral area of the city in 2000, 2010 and 2020

Source: Results of the work, October 2020

The analysis of figure 10 shows that the area of agglomerations increased from 1436.91 ha in 2000 to 4294.38 ha in 2010 and then to 11326.4 ha in 2020 . At the same time, the mosaics of crops and fallow land increased from 27740 , 7ha in 2000 to 25329.318 ha in 2010 then to 18049.2ha in 2020. These data show that the area of crops and fallows is decreasing in favor of that of the agglomerations. 
From 2000 to 2020, the area of cultivable areas was reduced by $9,691.5$ ha, or 484.57 ha per year. This drastic reduction in the area of agricultural areas reflects the importance of the changes taking place in the peri-urban area. Table III presents the summary of occupancy units from 2000 to 2020.

Table III: Summary of occupancy units between 2000 and 2020

\begin{tabular}{|c|c|c|c|c|c|}
\hline & $\begin{array}{l}\text { Sup } 2000 \\
(\mathrm{Ha})\end{array}$ & $\begin{array}{l}\text { Sup } 2020 \\
(\mathrm{Ha})\end{array}$ & $\begin{array}{l}\text { Difference } \\
\text { between } \\
2000 \text { and } \\
2020(\mathrm{Ha})\end{array}$ & $\begin{array}{c}\text { Annual } \\
\text { Growth Rate }\end{array}$ & $\begin{array}{c}\text { Balance } \\
\text { sheet }\end{array}$ \\
\hline Agglomerations & 1436,91 & 11326,4 & 9889,49 & 34,41 & Progression \\
\hline $\begin{array}{lr}\text { Mosaics } & \text { of } \\
\text { crops } & \text { and } \\
\text { fallows } & \end{array}$ & 27740,7 & 18049,2 & $-9691,5$ & $-1,74$ & Regression \\
\hline Swamps & 5783,96 & 5509,19 & $-274,77$ & $-0,23$ & Regression \\
\hline Body of water & 353,239 & 435,395 & 82,15 & 1,16 & Regression \\
\hline Planting & 1635,98 & 1632,35 & $-3,63$ & $-0,01$ & Regression \\
\hline
\end{tabular}

Source: Results of the work, October 2020

The analysis in Table III shows that between 2000 and 2020, the area of agglomerations has changed and the annual growth rate is $34.41 \%$. On the other hand, the mosaics of crops and fallows, swamps and plantations fell with respectively $-1.74 ;-0.23$ and -0.01 as the regression rate.

Until 2000, the area was marked by the presence of fallows, pineapple and corn fields, family estates, etc. and the price of a $500 \mathrm{~m} 2$ plot was around 2,000,000 CFA francs. From 2000 to 2020 , the changes noted during fieldwork confirm the changes that have taken place in this space formerly devoted to agriculture. The presence of churches and mosques, multi-storey houses, shops and workshops, palm groves, etc. shows that the landscape has undergone transformations over time. The few maize and cassava fields identified during surveys, particularly in peri-urban areas, are cultivated on private plots (Plate 1).

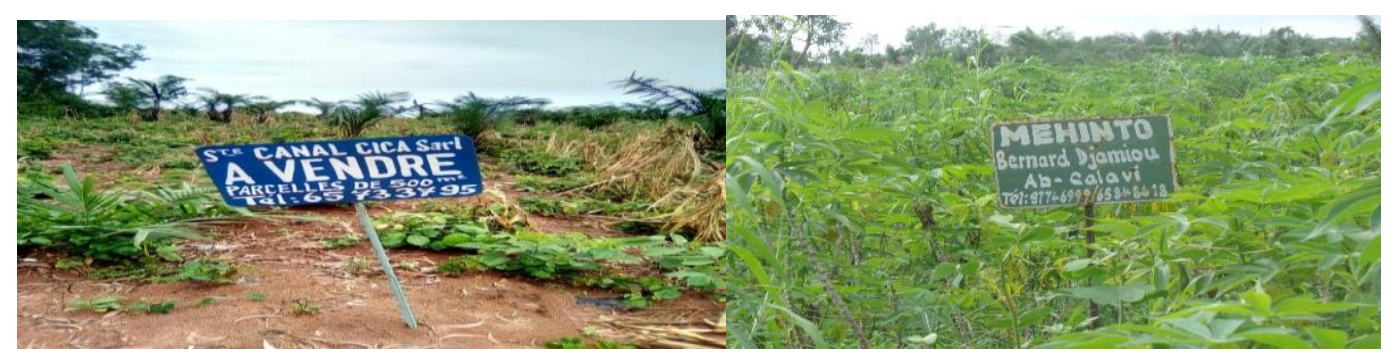

Plate 1: Examples of formerly agricultural plots bought by private individuals.

Shooting: A. B. Malomon, October 2021 
Vol. 06, No. 05; 2021

ISSN: $2456-8643$

Plate 1 shows formerly agricultural agricultural areas now acquired by private individuals (photo a) and in Ouèdo (photo b). Some buyers are freezing agriculture on these estates while waiting for the plots to increase in value before reselling them. These results bear witness to the human pressure on agricultural space in the outskirts of the city of Abomey-Calavi, resulting in the decline in agricultural production.

\subsection{Decrease in food production, a source of food insecurity}

The change in production for the main sectors during the period 2016 - 2021 is presented in Figure 11.

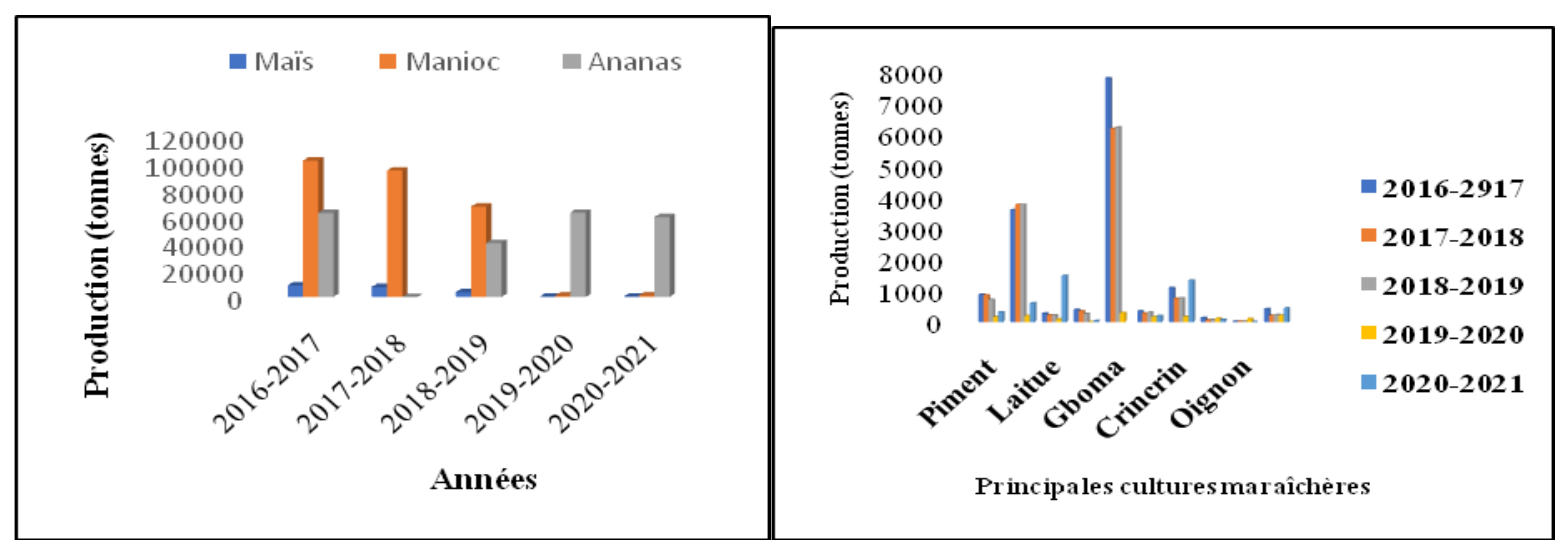

Figure 11: Evolution of the production of the main crops

Source: Cellule communale / ATDA / Atlantique, February 2021

From the analysis of Figure 11, it emerges that agricultural production, in particular those of the main crops identified, experienced a downward trend during the period considered. From 8,629 tonnes in 2016-2017, maize production increased to 252 tonnes during the 2020-2021 season; cassava production experienced the same downward trend during the period considered $(102,429$ tonnes in 2016-2017 and 1,129 tonnes in 2020-2021). Market gardening production is also experiencing a downward trend, like the pepper (892 tonnes in 2016-2020-2021 and 319.265 tonnes in 2020-2021); tomato (3,596 tonnes in 2016-2017 and 611.03 tonnes in 2020-2021). This situation is explained, among other things, by the reduction in the areas sown and the gradual abandonment of agriculture by producers who convert to other non-agricultural activities as shown in Figure 12. 


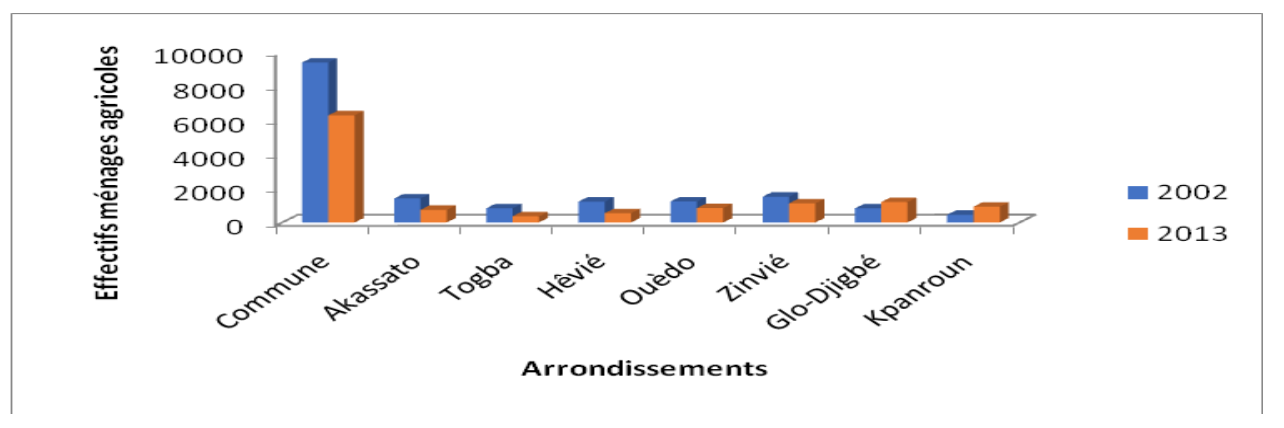

Figure 12: Evolution of the number of agricultural households from 2002 to 2013 in the peripheral area of the city of Abomey-Calavi

Source: INSAE 2002 and 2013

The figure shows that the farming population is getting smaller and smaller. Throughout the municipality, the number of agricultural households, which was 9,403 in 2002, rose to 6,298 in 2013. The same observation is made in the outlying areas of the city of Abomey-Calavi. The number of farm households has increased from 835 to 365 in the Togba district. In Akassato, the number of agricultural households also experienced a decline, going from 1,407 in 2002 to 741 in 2013. The same observation is made in Hêvié, Ouèdo and Zinvié where the number of households is respectively from 1,225 to 543 ( Hêvié), from 1238 to 848 (Ouèdo) and from 1517 to 1125 (Zinvié). This drastic reduction in the number of agricultural households in these periurban districts is explained by the fact that they are more exposed to peri-urbanization and, in turn, to land tenure problems. On the other hand, in the Arrondissement of Glo-Djigbé and Kpanroun, the number of agricultural households rose respectively from 826 to 1,202 and from 452 to 925 during the same period. This increase is explained by the fact that these two districts, unlike the others, are less exposed to peri-urbanization. Moreover, field surveys have shown that the productive capacity land market is still available and is particularly lively in the Kpanroun district. But it is gradually narrowing with the strong demand for "land deposits".

It can be deduced from this that agricultural land ownership is more preserved in Kpanroun (rural district) than in the other peri-urban districts. This is due to the urbanization of peri-urban districts which favors their human densification and which leads to changes in land use.

\section{DISCUSSION}

In the Municipality of Abomey-Calavi, the urban periphery is the site of major changes which are reflected in the reduction of cultivable land in favor of housing. Formerly agricultural households have sold off their land and hardly have any left for family farming.

These observations made in the Municipality of Abomey-Calavi are similar to those made by other authors.

Indeed, according to R. Aguejdad (2009, p.7), the artificialization of soils increases each year in France by $60,000 \mathrm{ha}$, or $6,000 \mathrm{~km} 2$ in 10 years. This is the equivalent of an agricultural department that disappears every 6 years. Concretely, 160 ha of "natural" spaces and more 
particularly spaces dedicated to agriculture, disappear every day by artificialization to transform into infrastructures, areas of activities, housing and recreation.

According to E. Houimli (2008, p. 35), the peri-urbanization process is generalized to most Tunisian cities, especially coastal ones, and the consequences are identical: destabilization of peri-urban agriculture and loss of large areas of fertile agricultural land. In the outskirts of Tunis, according to the author, urbanization consumes an average of 517 ha each year during the decades 1960-1970 and the trend accelerated in the 1980s. But, more serious, he adds, a quarter of these spaces consumed were agricultural land or provided for as such in the master plan.

According to N. Ticană (2013, p. 32), several factors are at the root of peri-urbanization; they are demographic, town planning, political, residential, economic or cultural. According to the author, a strong demographic dynamic is felt in these new emerging spaces and is essentially based on a positive migratory balance. New land use methods are observed with the reduction of agricultural space in favor of buildings.

According to P. J. Dossou et al. (2011, p. 9), since the early 1990s, the Municipality of SèmèPodji has experienced a new socio-economic dynamic. In a context of pressure exerted by the large neighboring cities (Cotonou and Porto-Novo), private actors are buying large estates to install residential or commercial or industrial infrastructure while the public authorities are investing in the realization of big works. Pressure on land is increasing, sales of land by peasants are increasing and prices are rising. Farming of land gives way to exploitation commercial and industrial, depriving peasant populations of their traditional resources.

In a study devoted to peri-urbanization and land speculation in the Municipality of AbomeyCalavi, AG Glèlè et al., $(2012$, p. 2) assert that the phenomenon of peri-urbanization generates the development of modern single-family homes, craft activities and services and promotes an exponential increase in the price of land formerly agricultural or set aside.

\section{CONCLUSION}

The dynamics observed in the outskirts of the city of Abomey-Calavi can be explained by both natural and anthropic factors. It results in a reduction of agricultural areas in favor of homes. Family farming is therefore in the grip of urbanization in this town. However, the primary function of this form of agriculture in the peri-urban space is to provide basic foodstuffs (vegetables, fruits, eggs and other small livestock products) to city dwellers. Its disappearance would cause city dwellers to travel long distances to stock up on these products; which will increase the price of said products.

It is therefore urgent that the local authorities develop and implement a management strategy for the peri-urban space that preserves family farming; this will facilitate the supply of urban dwellers with basic agricultural products.

\section{REFERENCES}


AGUEJDAD Rahim (2009): Urban sprawl and evaluation of its impact on biodiversity, from the reconstruction of trajectories to prospective modeling. Application to a medium-sized agglomeration: Rennes Métropole, $\mathrm{PhD}$ thesis, $374 \mathrm{p}$.

ATODJINOU Candide Mahouton, ATTANASSO Marie-Odile, ATTEMBA Roger (2015): Demographic dividend: how can Benin benefit from it? p.6.

DAUVERGNE Sarah (2011): Urban and peri-urban spaces for agricultural use in cities of subSaharan Africa (Yaoundé and Accra): an approach to intermediation in geography, Doctoral thesis in Geography, Ecole normale supérieure de Lyon, p. 391

DOSSOU Paulin Jésutin, ALLAGBE Simon, De-SOUZA Tatiana, NOUDAIKPON Grégoire, TOVISSOHE Alex (2011): Evolution and impacts of land use on the Benin coast: the case of the Municipality of Sèmè-Podji, 54 p.

GLELE Afiavi Gisèle., TOHOZIN Antoine, DOMINGO Etienne (2012): Peri-urbanization and land speculation in the Municipality of Abomey-Calavi, article, $19 \mathrm{p}$.

HOUIMLI Ezzeddine (2008): Factors of resistance and fragility of coastal agriculture facing urbanization: The case of the Sousse Nord region in Tunisia, Doctoral thesis in landscape sciences and architecture, ENGREF, pp: 113 -127.

MALOMON Atchamou Bola (2018): Governance of peri-urban agricultural land in the Municipality of Abomey-Calavi: State of play and challenges for local development, Research Master's thesis, DGAT / FASHS / EDP / UAC, 119 p.

UN (2014): World population situation in 2014, 48 p.

SCHWARTZ Daniel (1995): Sampling: from sampling to analysis. ORSTOM edition, $209 \mathrm{p}$.

TICANA Nicoleta (2013): The peri-urban extension of Bucharest since 1989, Doctoral thesis, Nantes Angers Le Mans University, p. 430

TORRE André and DARLY Segolene (2013): Land use and soils disposal: From competition to territorial governance (examples from land use conflicts in the greater Paris region). Renewable Agriculture and Food Systems. Cambridge University Press, 12 p.

IUCN (2004): Proceedings of the World Conservation Congress, 3rd session, Bangkok, Thailand, 17-24 November 2004, 87 p.

UNFPA (2007): State of the population in 2007, unleashing the potential of urban growth, $108 \mathrm{p}$.

VISSOH Ahotondji Sylvain (2012): Access and use of land in the towns of Dassa-Zoumé and Savalou, a contribution to the study of land in secondary towns in Benin. Single Doctorate Thesis, University of Abomey-Calavi, $313 \mathrm{p}$. 